\title{
Homewear in Brazil: evolution from 1976 to present
}

\author{
Mariana Costa Laktim ${ }^{1,2}\left(\mathbb{D} \cdot\right.$ Rita de Castro Engler $^{2}\left(\mathbb{D} \cdot\right.$ Raul Fangueiro $^{3}\left(\mathbb{D} \cdot\right.$ Joaquim Jorge Peixoto $^{3}(\mathbb{D})$ \\ Camilla Borelli ${ }^{4}$. Julia Baruque-Ramos ${ }^{1} \mathbb{E}$
}

Received: 15 June 2019 / Accepted: 9 October 2019 / Published online: 7 November 2019

(c) Springer Nature Switzerland AG 2019

\begin{abstract}
The traditional bride trousseau (homewear) was composed of bedding, table and bath textiles and household utensils that were necessary for her married life. Social changes and technological advances provided a new perspective and proportion for homewear textile sector. This study aimed to analyze the evolution of household linen (bedding, table and bath), from 1976 to 2019, in Brazil, related to composition of materials. Literature and magazines of this area were analyzed, notably Casa Vogue Brasil ("Vogue Home Brazil") and Casa Claudia ("Claudia Home") magazines. It concluded that the main employed material is cotton, followed in lesser extent by blends (notably cotton and polyester). The classic patterns predominate, especially the flat fabrics, ornamented with embroidery and classic design of flower and geometric prints, white and soft colors (clear beige, clear gray, etc.). These products represent the majority of sales in the domestic, but they could be non-competitive at the foreign market considering the price in relation to commodities from Asia and also lacking the necessary differentiation to meet these target publics.
\end{abstract}

Keywords Homewear $\cdot$ Cotton $\cdot$ Flax $\cdot$ Textile $\cdot$ Trousseau $\cdot$ Fiber

\section{Introduction}

The home textiles are composed of articles for home appliances, decoration, protection of household objects and also for the comfort of the human in your home [1]. The present study consisted of investigating the textile materials applied in the bedding, table and bath linen sector in Brazil, from the images and texts of Casa Vogue Brasil ("Vogue Home Brazil") and Casa Claudia ("Claudia Home") magazines from 1976 to 2019. The preliminary literature review was based on topics, with fundamental concepts to the understanding of the study, about the textile chain and aspects related to bedding, table and bath linen.

Over time, changes occurred, reflected in the type of fabric, confection, design and fashion, as the market needs. In Brazil, it is also observed that its characteristics have evolved over time, through textiles materials, manufacturing processes and fashion (design), with a growing economic impact. The importance of the textile industry to Brazil is presented in the surveys conducted by the Brazilian Textile Industries Association (ABIT) between 2014 and 2017: The sector employs 1.5 million direct workers and 8 million indirect workers, making it the second largest employer in the industry of transformation in Brazil. It has 32,000 formalized companies, which are the fourth largest manufacturing production park, fifth largest textile producer, fourth largest producer of knitwear and the second largest producer of denim in the world, have the complete textile chain and have self-sufficiency in cotton production. It produces 9.4 billion pieces by year, of which about 5.3 billion are clothing, and is a world reference in beachwear, jeanswear and homewear (home textiles). In

$\triangle$ Mariana Costa Laktim, marilaktim@hotmail.com | ${ }^{1}$ School of Arts, Sciences and Humanities, University of São Paulo, Av. Arlindo Bettio, 1000, São Paulo, SP 03828-000, Brazil. ²Design School, Minas Gerais States University, Av. Pres. Antonio Carlos, 7545, Belo Horizonte, MG 30270-010, Brazil. ${ }^{3}$ University of Minho, Campus de Azurem, 4800-058 Guimarães, Portugal. ${ }^{4}$ FEl University Center, Av. Humberto de Alencar Castelo Branco, 3972-B, São Bernardo do Campo, SP 09850-901, Brazil. 
general terms, Brazil is one of the largest consumers of textile products in the world today, but in terms of international exports its contribution is small, ranking 26th position. Referring homewear, the main employment of the fibers in tons in the years 2013 to 2017 was: cotton $(1,032,858-1,032,954 \mathrm{t})$, flax $(1,103-717 \mathrm{t})$ and polyester $(121,160-105.963 \mathrm{t})$ [2].

It is noticed this sector advances constituting an important role in the textile production. The innovation models found demonstrate the evolution process of design and the home fashion industry, as well as the increase in the market economy.

\subsection{Textile chain production process}

According to Costa and Rocha [3], the textile productive chain has two origin sources: the natural one (vegetal, animal or mineral) and the chemical, for artificial and synthetic fibers. It consists of the manufacture of this raw material by spinning process, followed by weaving or knitting. This product is benefited with several chemical and physical processes, emphasizing fundamentally the dyeing and the printing, to be able to finally arrive at the confection. In this is carried out the planning, folding, spreading, cutting and sewing. However, the product in this stage can go back to the textile processing and thus reach the final consumer.

In the final stage, the products can reach the consumer in the form of clothing and housewear items (bedding, table, bath linen, decoration and cleaning). In addition to these traditional uses, fabrics can also be employed in several industrial sectors (cotton filters, car interior components, packaging, etc.) [3]. According to data from 2014, in Brazil there are 19 companies producing fiber and filaments that supply raw material to more than 29 thousand manufacturing industries [4].

\subsection{Textile fibers}

Textile fiber is a generic term for various types of materials, natural or artificial, consisting of filiform elements, which form the basic elements for textile purposes. They are characterized by having a length at least one hundred times greater than their width or diameter. The other characteristics are tensile strength, absorption, elongation, elasticity, flexibility, abrasion resistance, etc. [5].

The textile fibers are divided basically into two classes: natural, from nature, and man-made. The fibers of vegetal, animal and mineral origin are classified as natural fibers, since they do not need the interference of the man for its formation. The chemical fibers represent an alternative created by the man to supply the deficiencies found in the natural fibers; they are classified in two classes: artificial and synthetic. Artificial fibers are produced by man, but natural fibers are used as the starting point for their manufacture, such as viscose, acetate and triacetate fibers, composed of cellulose [6]. Synthetic fibers, in turn, come from the petrochemical industry, such as: polyester, polyamide and acrylic. There is another category of fiber, elastane, with very peculiar characteristics [7]. Table 1 indicates the evolution of consumption of fibers of 1976 and 2018 in Brazilian textile industry [8].

The textile industry is composed of the spinning, weaving and knitting industries, which handled US $\$ 17.06$ billion in 2016. This total value refers to the US $\$ 5.95$ billion revenues from the spinning industries, US\$ 8.02 billion weaving and US $\$ 3.08$ billion of knitting [8].

Within these previous considerations, the main characteristics of fibers of cotton, flax, wool and polyester are presented below, since they constitute the majority of all the fibers employed in the bedding, table and bath linen sector.

\subsection{Cotton fiber}

The cotton and flax are the oldest natural plant fibers. Cotton fiber develops from a single seed cell. It is affiliated to the genus Gossypium L. This genus covers 20 species of herbaceous plants, four of which presents greater commercial importance: Gossypium barbadense L. (known as "Egyptian cotton," the fiber is long and thin); Gossypium herbaceum L. and Gossypium arboreum L. (also called Indian or Asian, short and thick fibers); and Gossypium hirsutum L. (stands between the fiber of Asian and Egyptian cotton, their length and fineness are quite variable and constitutes more than $90 \%$ of world production). Cotton length variation ranges from $18 \mathrm{~mm}$ (shorter) to above $40 \mathrm{~mm}$ (longest) [9].

In the textile industry, cotton fiber is the most important for several reasons as its low cost, requiring neither mechanical nor costly chemical treatment. Because it is washable and more resistant than wool, from its core it extracts the edible oil and the grinding of its residues in bran is used for feeding the cattle or as fertilizer in the planting [10].

Cotton has a natural absorbency, soft touch and high absorbent property. It is the most cultivated natural fiber and one of the most important in the world. However, it should also be considered as negative points that your tissues will wrinkle easily and your shrinkage rate is high [11, 12].

Cotton is among the most respectable fiber crops in the world. According to the Brazilian Association of Cotton Producers-ABRAPA [13], there are around 35 million hectares of cotton planted all over the planet, and in Brazil there are about 1.13 million hectares (where one hectare 


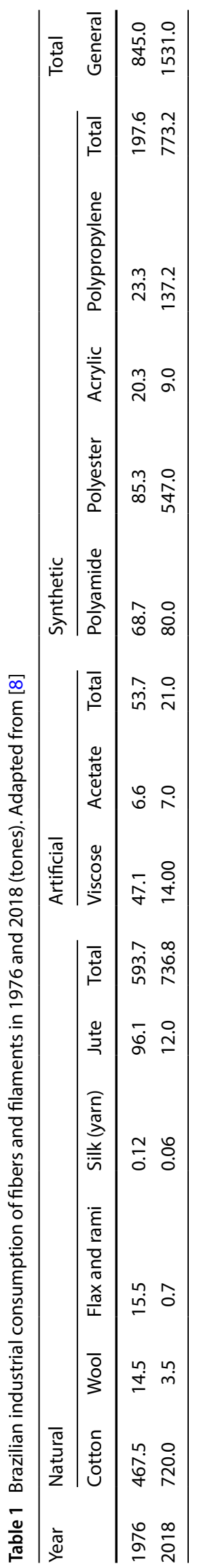

corresponds to 10,000 square meters). The production of cotton products, in the $2016 / 2017$ harvest, generated US\$ 72.96 billion in sales, with the retail link being grouped according to its different products and the sales, as following (in US\$ billion): 54.75-clothing; 12.33-home linen; 3.69-other confections; and 2.19-socks and accessories. It is worthy of mention that the home linen sector is increasing the cotton consumption.

\subsection{Flax fiber}

Flax fiber is originated from an annual plant, the Linum usitatissimum. The interior of the bark of the plant has long cells, thin and thick walls, whose fibrous elements are composed [5].

Flax culture is performed in both hot climates and temperate and subtropical regions; its life cycle is short. After flowering, which lasts for a few hours, three weeks later the plant with the stem will measure between $90 \mathrm{~cm}$ and $120 \mathrm{~cm}$ in height and will be ready to start (for full use of the stem). The process, from the cultivation to the fiber of flax, is: soil preparation, selection of varieties, seeding, flax growth, harvesting, maceration and threshing; all this process determines fiber quality, and only the unbranched portion of the stem has commercial value for use as textile fibers [14].

The long fibers are sent to the textile industry, and the short ones are common in the production of ropes, in the stationary, manufacture of agglomerates along with residues of wood, in the lining of stables and others. Flax is a strong fiber, making fabrics durable and wash resistant; when wet its resistance can reach up to $20 \%$ higher than dry fabric $[9,10]$. The resistance, length and capacity as thermal insulation are superior in flax compared to the cotton fiber.

\subsection{Wool fiber}

It is the earliest employed animal fiber, being used primarily as leather until the discovering that the fibers could be turned into yarns and, from they, in fabrics. Fragments of woolen fabrics were found in Egypt 4000 years BC, and there are indications that the first fabrics of woven wool were manufactured in Mesopotamia [5].

The animals are sheared once a year, usually in the spring. For shearing, a kind of electric scissors is used, similar to hair clippers. After removing the fleece, it is tied and separated by its kind of fineness, determining the type of product will be made with the separate wool. Posteriorly, the raw wool is washed and rinsed in several tanks for removal of impurities, and it is sorted by carding (cylinders covered by fine wire teeth, transforming into a sort of thin veil in parallel positions). Then it is carded (for the 
production of soft and slightly twisted yarns) or combed (thinner and stronger yarns) [10].

\subsection{Polyester fiber}

Synthetic polyester was obtained in 1833 by Gay-Lussac and Pelouze by heating of lactic acid. However, it became known in the 1940s as linear molecular structure when Carothers and his auxiliaries obtained aliphatic polyesters. The raw materials used to obtain the polyester are paraxylene, terephthalic acid (TPA), dimethyl terephthalate (DMT) and ethylene glycol [5].

Polyester is the cheapest textile fiber, and there is a high range of polyester fibers such as Polyester/Meryl ${ }^{\circledR}$ (polyester and polyamide microfibers), Tergal $^{\circledR}{ }^{\circledR}$-Cotton (short fiber mixed with cotton pieces), Tergal ${ }^{\circledR}$-Tech Fiber (Tergal-Lofty fiber with high performance and used in filling blanket applications). Its water absorption is very low, but presents high mechanical resistance $[9,10]$.

Polyester fiber is one of the most consumed fibers (reaching $70 \%$ in various textile sectors). However, it has a hydrophobic and electrostatic nature. For better moisture transport, research has been conducted especially with the use of multifilaments and ultrafine filaments [11, 12].

Multifilament polyester yarns are made by adding many continuous filaments together. They are characterized by their high strength, good chemical properties, acceptable elasticity and their circular cross section. In addition, the voids between these filaments form capillary channels and facilitate the flow of liquid. In knitted fabrics, the use of multifilament polyester yarns instead of monofilament can facilitate the transport of moisture and the absorption of liquids [11].

Ultrafine filaments or polyester nanofilaments with diameters in the range of a few nanometers and lengths up to kilometers are used in different important technological applications such as functional fabrics, biomedicine, composites, etc. Polyester nanofilaments are characterized by their high tenacity, large surface area per unit mass and small pore size [12].

The polyester fibers are used as components of the blended yarns, taking advantage of their good properties, such as high tensile and abrasion resistance, dimensional stability, hydrophobic as well as easy care in order to increase the use of the value of the blended yarns [15].

\subsection{Blend cotton and polyester fiber}

Blends of polyester and cotton fibers are widely used by the textile industry. According to Chen and Zhao [15], the analysis of $65 / 35 \%$ and $33 / 67 \%$ polyester/cotton (PES/CO) blended yarns showed better performance characteristics than $100 \%$ cotton or $100 \%$ polyester yarns.
The use of multifilament yarns in fabrics is also an alternative to replace cotton in some uses, as in the case of strenuous activities, when the user releases sweat, feeling discomfort. Polyester fibers with long capillaries provide better transport and drive the perspiration to be evaporated [16].

\subsection{Fibers in bedding, table and bath products}

In historical documents, the first textile fibers employed in antiquity were the natural ones, such as flax, cotton, wool and silk. Natural fibers are still very common in Home Fashion, since each fabric stands out in a product, adding also social status in the bedding, table and bath linen. Cotton stands out in the production of bath towels, due to its excellent absorption, comfort and fabric softness. It is very common also in bedding linen (bedspread, sheets, pillow cases, etc.). Egyptian cotton, which is considered one of the best in the world, is used to make bedding and bath articles, due to its unique properties of softness, touch and comfort in the contact of the human skin with the fabric. In the segment of Home Fashion, wool is used in rugs and blankets, but often replaced by its substitute, acrylic fiber. The silk can be employed in rugs, upholstery, bedding and blankets, providing to these products great value in the market due to their nobility [10].

The Industrial Revolution led the crossing of borders, opening the industrial textile market, encouraging new creations, initiating the production of man-made fibers (such as viscose, nylon, polyester, acrylic fiber, etc.), industrial dyeing, printing and processing. In the twentieth century, the textile design broke off the traditional floral prints, opening options for abstract shapes and others [17].

Historically, the house's linen was sewn and embroidered manually, employing textiles composed of natural raw materials in basic colors. With the Industrial Revolution, the textile technological advances provided a new perspective and proportion in the production and confection of the fabrics. In addition, textile designers afforded creativity in new collections of prints and models on conventional and technological fabrics. This set of innovations followed the needs of social changes and their new demands.

\section{Methodology}

An extensive bibliographic research was carried out. Notably, for the analysis of the evolution of the textile materials, Casa Vogue Brasil ("Vogue Home Brazil") and Casa Claudia ("Claudia Home") magazines were consulted. These magazines are the most relevant in this sector, as follows: 
- Casa Vogue Brasil ("Vogue Home Brazil") had the first Brazilian edition published in May 1975, being the first edition in Latin America. Vogue is the most important, respected and influential fashion magazine in the world published since 1892 by Condé Nast Publications in 21 countries. It monthly publishes articles of Fashion Home universe. The data were collected from 1975 until March 2019.

- Casa Claudia ("Claudia Home") was published from 1977 to August 2018 by publishing company “Editora Abril." It was a Brazilian magazine of decoration, being one of the main magazines of this sector in the country. Despite this, "Editora Abril" is the leader in 21 of the 25 segments in which it operates and has seven of the 10 most read magazines in the country. The data were collected from 1977 until August 2018, when the last edition of this magazine was published.

The magazine collections were accessed in the libraries of "Armando Alvares Penteado Foundation" (FAAPBrazil) and "Mineira Foundation of Education and Culture" (FUMEC-Brazil). For Casa Vogue Brasil, the study of 43 years of editions (1976-2019) and for Casa Claudia, the study of 41 years (1977-2018) was carried out.

All the images that presented products related to bedding, table and bath linen were collected. For this process, the IRIScan Book 3 portable scanner (Canon Co., USA) was employed. It should be noted that it was not possible to access all editions published in the cited periods for each magazine due to the discontinuity of the copies of the collections of FAAP and FUMEC, despite the attempt to complement the joint research by the two collections.

\section{Results and discussion}

The designers have to understand the aesthetic sensibility and the need of the target customers and creating innovations and concepts in fashion to satisfy them. All coordination of texture, colors and prints should be in harmony with the trends and environment of the house [1]. Many companies in bedding, table and bath linen segment have begun to invest in design as a distinguishing factor of the pieces, transforming the old trousseau into the modern concept of Homewear or Home Fashion, following fashion trends by improving shapes, colors, textures, materials and patterns. This process transformed the "marriage trousseau" into fashion articles for the home [18].

Natural fibers are still very much employed; previously flax fiber and currently cotton is used in the production of bath towels, bedding linen and other articles. Egyptian cotton is used for bedding up to 1000 threads per inch of warp, providing unique properties of softness, touch and comfort. Wool is used on rugs and blankets, but often replaced with acrylic fiber. However, various products are found with artificial and synthetic fibers (such as viscose, acetate, polyester, acrylic fiber, etc.) with various processings and finishes. This follows the evolution of the world consumption of textile fibers in the last 60 years, with an increase in consumption of synthetic fibers in detriment of natural fibers [17].

Cotton is the most important natural textile fiber. In 2004 , cotton had a demand of $54 \%$ of fabrics worldwide. It presents properties of appearance, comfort, nice touch and durability, being recommended for hot weather. It is used in clothes, work uniforms, upholstery, curtains, carpets, towels, bedding linen, etc. [10, 17].

In present study, the investigation of textile materials applied in the bedding, table and bath linen sector in Brazil was carried out, from the images and texts of Casa Vogue Brasil ("Vogue Home Brazil") and Casa Claudia ("Claudia Home") magazines (from 1976 to 2019).

In Casa Vogue Brasil editions, the textile materials of bedding, table and bath linen from 1976 to 2019 were analyzed as presented in Table 2:

Summarizing data in Table 2 and Fig. 2, from 1976 to 2019 (284 editions), 4295 images were collected from which 3172 were analyzed, resulting in 2086 (65.8\%) cotton; 142 (4.5\%) Egyptian cotton; 363 (11.4\%) blend (cotton and polyester); 171 (5.4\%) flax; 128 (4.0\%) wool; 100 (3.2\%) polyester; and $182(5.7 \%)$ others.

Casa Vogue Brasil (1976-2019) presents the most relevant styles in the bedding, table and bath linen market. As shown in Figs. 1 and 2, the classics are marked in the preference of style presentation with emphasis on $100 \%$ cotton fabric in bedding, table and bath products, being separated in this research articles made of regular cotton and Egyptian cotton. In addition, according previous studies performed by present authors, flat fabrics in white color and embroidery as outstanding ornament of the style are also predominant in these fashion home products [21, 22].

Table 2 Number of collected and analyzed images related to bedding, table and bath linen from 1976 to 2019 in Brazil, according the research performed in all editions of Casa Vogue Brasil. Adapted from [19-21]

\begin{tabular}{lcccl}
\hline Period & Editions & $\begin{array}{l}\text { Collected } \\
\text { images }\end{array}$ & $\begin{array}{l}\text { Analyzed } \\
\text { images }\end{array}$ & $\begin{array}{l}\text { Icono- } \\
\text { graphic } \\
\text { example }\end{array}$ \\
\hline $1976-1979$ & 11 & 132 & 100 & Fig. 1a \\
$1980-1989$ & 39 & 454 & 317 & Fig. 1b \\
$1990-1999$ & 24 & 294 & 203 & Fig. 1c \\
$2000-2009$ & 96 & 1574 & 1250 & Fig. 1d \\
$2010-2019$ & 113 & 1841 & 1302 & Fig. 1e \\
Total & 283 & 4295 & 3172 & - \\
\hline
\end{tabular}




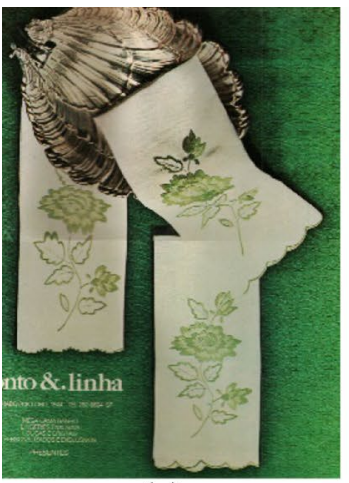

(a)

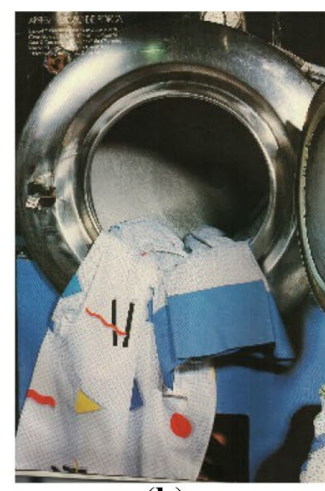

(b)

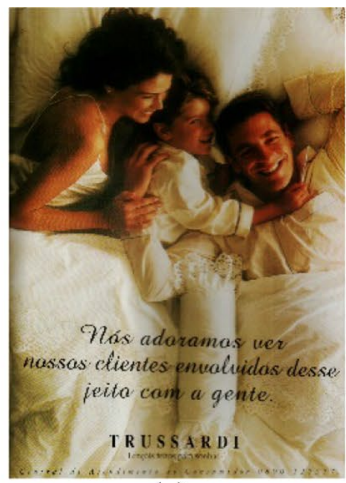

(c)

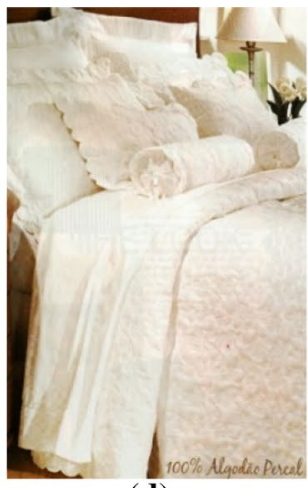

(d)

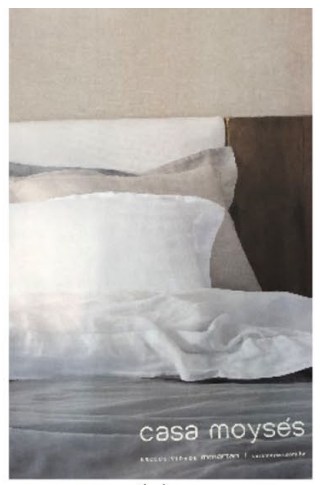

(e)
Fig. 1 Examples of: a hand towel 100\% flax; b bedding linen $100 \%$ cotton; c bedding linen 100\% Egyptian cotton; $\mathbf{d}$ bedding linen $100 \%$ cotton percale; e bedding linen 100\% flax. Source: Compiled from Casa Vogue Brasil ("Vogue Home Brazil Magazine") (Sao Paulo:
Globo and Condé Nast) [19]: a 1978, v.11, n.41A, p.111; b 1986, v.01_02, n.1, p.100; c 1997, v.04, n.4, p.069; d 2005, v.03, Ed.236, p.186; e 2019, v.01, ed.401, p. 013

Table 3 Number of collected and analyzed images related to bedding, table and bath linen from 1977 to August 2018 in Brazil, according the research performed in all editions of Casa Claudia. Adapted from $[20,21,23]$

\begin{tabular}{lcccl}
\hline Period & Editions & $\begin{array}{l}\text { Collected } \\
\text { images }\end{array}$ & $\begin{array}{l}\text { Analyzed } \\
\text { images }\end{array}$ & $\begin{array}{l}\text { Icono- } \\
\text { graphic } \\
\text { example }\end{array}$ \\
\hline $1977-1979$ & 7 & 113 & 97 & Fig. 3a \\
$1980-1989$ & 27 & 448 & 390 & Fig. 3b \\
$1990-1999$ & 51 & 701 & 644 & Fig. 3c \\
$2000-2009$ & 116 & 2281 & 1882 & Fig. 3d \\
$2010-2018$ & 94 & 2358 & 1878 & Fig. 3e \\
Total & 295 & 5901 & 4891 & - \\
\hline
\end{tabular}

In Casa Claudia editions, the textile materials of bedding, table and bath linen from 1977 to August 2018 were analyzed as presented in Table 3.

Summarizing data in Table 3 and Fig. 4, from 1977 to August 2018 (295 editions), 5901 images were collected from which 4891 were analyzed, resulting in 3303 (67.6\%) cotton; 104 (2.1\%) Egyptian cotton; 823 (16.8\%) blend (cotton and polyester); 139 (2.8\%) flax; 170 (3.5\%) wool; 148 (3.0\%) polyester; and 204 (4.2\%) others.

Casa Claudia (1977-2018) presents the most relevant styles in the bedding, table and bath linen market. As shown in Figs. 3 and 4, also in the research performed on data of this magazine, it is clearly observed that the classics are marked in the preference of style presentation with emphasis on $100 \%$ cotton fabric in bedding, table and bath products, being separated in this research articles made of regular cotton and Egyptian cotton. In addition, according to a previous study performed by present authors, the classic patterns, especially flat fabrics, white and soft colors (clear beige, clear gray, etc.), and classic cotton, Egyptian cotton and linen trousseau items. 


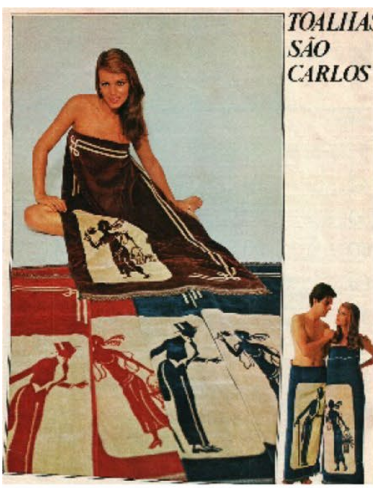

(a)

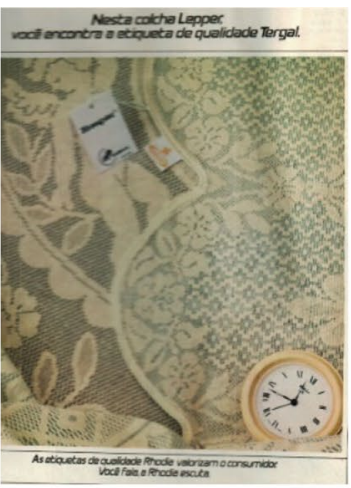

(b)

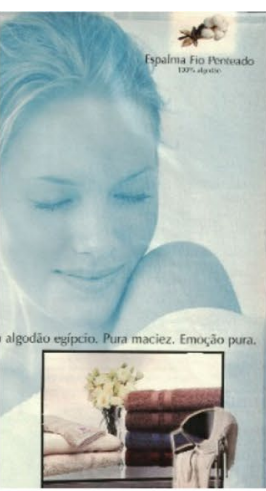

(c)

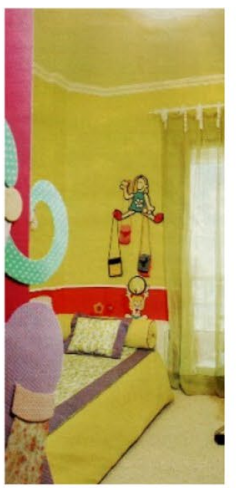

(d)

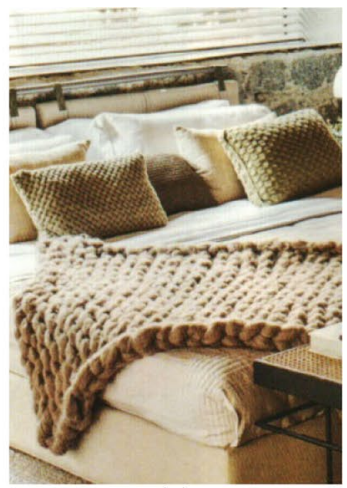

(e)
Fig. 3 Examples of: a bath towel-100\% cotton; b table cloth$100 \%$ polyester; $\mathbf{c}$ bath towel-100\% Egyptian cotton; $\mathbf{d}$ bedding linen set-(mixed: cotton and polyester) and e blanket-100\% merino wool. Source: Compiled from Casa Claudia ("Claudia Home

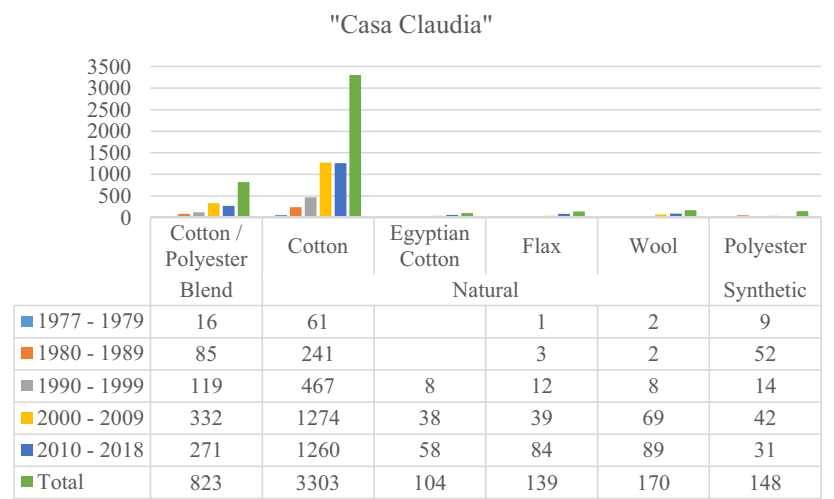

Fig. 4 Number of articles (with description of constituent material) related to bedding, table and bath linen from 1976 to August 2018 in Brazil, according the research performed in all issues of Casa Claudia. Adapted from [20, 21, 23]

design of flower and geometric prints are predominant in these fashion home products [21,22].

Analyzing data presented in Fig. 4, the clear predominance of cotton in bed, table and bath articles is demonstrated, being separated in this research articles made of regular cotton and Egyptian cotton. As observed previously for Casa Vogue Brasil data, here also the presence of articles of other natural fibers such as flax, silk and wool represents a minority. It was observed in the last year (2018) a significant increase in wool and flax fabrics in the products. Although blends of cotton and polyester are also fairly employed in the production homewear products for cost-sensitive publics, these articles and other ones with different fiber compositions (natural or man-made) were found in lesser extent in this research. These results agree with the market data presented in Table 1 (consumption of fibers of 1976 and 2018 in Brazilian textile industry), in
Magazine") (Sao Paulo: Abril) [23]: a 1979, v.12, Ed. 219A, p.004; b 1982, v.05, Ed. 248A, p.047; c 1998, v.02, Ed.13, p.026; d 2001, v.01, Ed.25, p.059; e 2018, v.07, ed.42, p.109

which cotton consumption stands out in first place followed by polyester fiber.

Thus, even considering that the analyzed magazines are for publics of high (Casa Vogue Brasil) and medium (Casa Claudia) purchasing power in the Brazilian context, it could be concluded in the same way that the preference of cotton articles in domestic market is mainly due to the tradition of the use of it in articles related to the trousseau.

Natural fibers, such as cotton, wool, flax, are predominant in the home textile world industry. Currently, artificial fibers are also used, including polyester, viscose, acrylic, etc. (Table 1). Polyester dominates the carpet and curtain segments due to their properties, such as tensile strength, resistance to the heat, abrasion and moths and mildew. The consumption of cotton, synthetic fibers and wool plus other animal fibers in the total household textile production represents $38 \%, 37 \%$ and about $6 \%$ respectively. Flax represents only $0.1 \%$ of all fibers consumed in home textile production. Information on the remainder fiber percentage was not identifiable because its general use was not classified or remained unspecified in the fiber categories. The cotton has preferential application in various items of the bedding, table and bath linen sector [1].

Brazilian textile production has been increasing slightly from 2010 to 2014, with cotton production from $13,140,038(2010)$ to $15,745,728$ (2014), synthetic fabric articles from 7,171,412 (2010) to 8,532,124 (2014) and articles of other natural fabrics from 442,040 (2010) to 613,265 (2014) [4].

In the present study, textile materials applied in the bedding, table and bath linen sector were considered. According the results, cotton homewear products were the most present in the both analyzed magazines along the 40 years. Among these homewear cotton products, bath towels have received further technological development. 
Cotton fiber is often used because of the polarity of the cellulose, which allows the fabric to absorb water easily. One of the most important innovations in the manufacture of yarns for towels has been the introduction of low twist yarns. These special yarns are spun with longer cotton fibers with a very low twist. This spinning technology makes the towel more absorbent by providing each cotton thread with a hollow core that absorbs moisture and, which, combined with the long cotton fiber makes the bath towel feel softer. In addition, cotton bathrobes made with fabrics incorporating this technology are suitable for use in hot climates because they tend to absorb better the perspiration [1].

According to Das [1], the most important factor in the consumer's choice of bath towels is the absorption and then is the softness and the type of fiber. The brands are relative and of little importance. Regarding cotton incorporated into the lifestyle, $91 \%$ of female consumers consulted said they prefer thicker towels and 94\% said they like their towels as soft as possible. The two most important factors that quote when buying a bath towel are absorbency (82\%) and softness (83\%). Consumer preferences regarding fiber type were not mentioned in this study.

For the origin of new homewear products, besides the technological development and its dissemination [24], it is necessary to aggregate contributions from fashion and design, considering styles and trends. Fashion represents what is in vogue, in evidence and is an immaterial phenomenon, with changing trends, style and design, at given intervals of time [25-28]. Trends are inclinations and repetitions of certain behavior and style. Trends are determined by fashion institutions, but always seek to present the new. The determination of trends by the components of the production chain aims to reduce the risk in the development of a collection of products $[26,28]$.

The present study recorded and collected information from the Brazilian bedding, table and bath linen sector in the historical context (1976-2019), cataloging images and texts of Casa Vogue Brasil (4295 collected images) and Casa Claudia (5901 collected images) and analyzing the trajectory of textile material evolution in this sector over the last four decades in Brazil.

In this scenario, the association of new attributes to bedding, table and bath products is considered viable and urgent, especially in the design and new technologies applied to the products. Among these attributes, it is possible to highlight the need for greater boldness and relevance in the effects of standardization, colors and attributes applied to fabrics, offering an innovative and affordable product, which can be accessible to various social classes. Within the innovations that have been offered by the market, the caution regarding the comfort and functionality of the final product is fundamental, being of great value to acquire credibility in the market. It is also important to emphasize the need to preserve nature (conscious and sustainable production structure); the rescue of traditional knowledge (the importance of acquiring the trousseau for each group in society); qualification in the design, modeling and finishing of products destined to the fashion sector; access to new consumer markets; and the encouragement of conscious consumption.

\section{Conclusions}

Casa Vogue Brasil and Casa Claudia present the most relevant styles in the bedding, table and bath linen market. The classics are marked in the preference of style presentation in these fashion home products, being predominant in the first publication flat fabrics in white color and embroidery as outstanding ornament. In the second one, flat fabrics, white and soft colors (clear beige, clear gray, etc.) and classic design of flower and geometric prints are predominant. In both cases, there is emphasis on cotton fabrics for bedding and bath products. It was possible to observe the European influence in the Brazilian fashion trends, employing the flax fabrics in both bedding linen and kitchen products as well as in the clothing. These products are presented representing the majority of sales in the domestic, but they could be non-competitive at the foreign market considering the price in relation to commodities from Asia and also lacking the necessary differentiation to meet these target publics. In addition, unlike other countries in the world, in Brazil the trousseau is associated with traditional marriage values, emulating aesthetic patterns from the past, in which the bride embroidered her own trousseau as part of the marriage dowry. The maintenance of these standards by the Brazilian manufacturers is interesting to maintain sales in the domestic market, but a limitation for export products destined to audiences with different values and aesthetic tastes and with a greater disponibility of items including variety of surface designs and technological innovations.

Acknowledgements The authors gratefully acknowledge the funding by CAPES-Coordenação de Aperfeiçoamento de Pessoal de Nível Superior ("Brazilian Federal Agency for Support and Evaluation of Graduate Education") and and FAPEMIG_Fundação de Amparo à Pesquisa do Estado de Minas Gerais ("Minas Gerais State Research Support Foundation").

\section{Compliance with ethical standards}

Conflict of interest The authors declare that they have no conflict of interest. 


\section{References}

1. Das S (2010) Performance of home textiles, 1st edn. Woodhead Publishing India PVT LTD, New Delhi

2. IEMI (2018) Instituto de Estudos e marketing industrial ("Institute of Industrial Studies and Marketing") Brasil Têxtil 2018 Report of the brazilian textile industry sector, 18th edn. IEMI, São Paulo

3. Costa ACRD, Rocha ERPD (2009) Panorama da cadeia produtiva têxtil e de confecções e a questão da inovação ("Overview of the textile and clothing production chain and the question of innovation") In: BNDES Setorial n. 29, BNDES, Rio de Janeiro, pp 159-202. https://web.bndes.gov.br/bib/jspui/bitst ream/1408/1309/2/BS\%2029_final\%20A.pdf. Accessed 5 May 2019

4. IEMI (2015) Instituto de Estudos e marketing industrial ("Institute of Industrial Studies and Marketing") Brasil Têxtil 2015 Report of the Brazilian textile industry sector, 15th edn. IEMI, São Paulo

5. Aguiar Neto P (1996) Fibras Têxteis ("Textile Fibers"), vol I and II. SENAI-CETIQT, Rio de Janeiro

6. Nierstrasz V, Cavaco-Paulo A (2010) Advances in textile biotechnology. Elsevier, Cambridge

7. Romero L, Vieira JOWM, Medeiros LARD, Martins RF (1995). Fibras artificiais e sintéticas ("Man-made and synthetic fibers"). In: BNDES Setorial n. 1, BNDES, Rio de Janeiro, pp 54-66. https:// www.bndes.gov.br/SiteBNDES/export/sites/default/bndes_pt/ Galerias/Arquivos/conhecimento/bnset/set105.pdf. Accessed 16 Apr 2019

8. ABIT (2017) Associação Brasileira da Indústria Têxtil e da Confecção ("Brazilian Association of Textile and Confection Industry). Perspectivas do setor têxtil e de confecção - desafios e oportunidades ("Perspectives of the textile and clothing sector - challenges and opportunities"). 24 March. https://www.gs $1 \mathrm{br}$ .org/setores/Documents/apresenta\%C3\%A7\%C3\%A3o_GS1. pdf. Accessed 16 Apr 2019

9. Maluf $E$, Kolbe W (2003) Dados Técnicos para a Indústria Têxtil ("Technical Data for the Textile Industry"). 2nd ed. IPT - Instituto de Pesquisas Tecnológicas do Estado de São Paulo and ABIT Associação Brasileira da Indústria Têxtil e de Confecção, São Paulo

10. Pezzolo DB (2009) Tecidos: histórias, tramas, tipos e usos ("Fabrics: stories, fillings, types and uses"), 2nd edn. Senac, São Paulo

11. Yip J, Ng SP (2008) Study of three-dimensional spacer fabrics: physical and mechanical properties. J Mater Process Technol. https://doi.org/10.1016/j.jmatprotec.2007.12.073

12. Chronakis IS (2010) Micro-/nano-fibers by electrospinning technology: processing, properties and applications. In: Qin I (ed) Micromanufacturing engineering and technology, 1 st edn. Elsevier, Oxford, pp 264-286

13. Rocha J (2018) Relatório de Conclusão da Safra de Algodão 2016/2017 - ABR e BCl. Versão Final. Certificação Algodão Brasileiro Responsável (ABR) e Licenciamento Better Cotton Initiative (BCI) ("2016/2017 Cotton Crop Completion Report - APR and $\mathrm{BCl}$. Final version. Responsible Brazilian Cotton (ABR) Certification and Better Cotton Initiative (BCI) Licensing"). 14 March
2018. Associação Brasileira de Produtores de Algodão ("Brazilian Association of Cotton Producers"). https://www.abrapa.com. br/Documents/Sustentabilidade/Relat\%C3\%B3rio_de_Concl us\%C3\%A3o_da_Safra_de_Algod\%C3\%A3o_2016-2017_Programa_ABR_e_BCl.pdf. Accessed 16 Apr 2019

14. Haubrich L (2018) Flax: production and origin. https://aworl d.com.br/2018/04/02/amendoa-linho/. Accessed 20 Mar 2019

15. Chen Q, Zhao T (2016) The thermal decomposition and heat release properties of the nylon/cotton, polyester/cotton and Nomex/cotton blend fabrics. Text Res J. https://doi. org/10.1177/0040517515617423

16. Sajjadi A, Sheikhzadeh M, Rikhtehgaran R, Hajrasouliha J (2015) Prediction of fabric handle value using ordinal regression model. J Text Inst. https://doi.org/10.1080/00405000.2014.977543

17. Kadolph SJ (2007) Textiles, 10th edn. Pearson Education, New Jersey

18. Pinto DF, Barbosa RCA, Brito Mota MD (2010) Enxoval de noiva e a moda - da dádiva ao homewear ("Bridal trousseau and fashion - from gift to homewear"). ModaPalavra e-periódico 3(6):9-18

19. Casa Vogue Brasil (1976-2019) Globo and Conde Nast, Sao Paulo

20. Laktim MC, Giacomin AM, Silva-Santos MC, Santos HN, Borelli C, Baruque-Ramos J (2017) Trousseau: the predominance of cotton in its articles. Proc Eng. https://doi.org/10.1016/j.proen g.2017.07.012

21. Laktim M C (2018) Cama, mesa e banho: desenvolvimento de materiais e processos têxteis, design e moda no Brasil (19762017) ("Trousseau (Home Fashion): development of materials and textile processes, design and fashion in Brazil (1976-2017)"). PhD Thesis. University of São Paulo

22. Laktim MC, Giacomin AM, Silva-Santos MC, Santos HN, Borelli C, Baruque-Ramos J (2017). Trousseau: economic and design aspects from the second half of 20th century in Brazil. In: IOP conference series: materials science and engineering. https:// doi.org/10.1088/1757-899x/254/17/172015

23. Casa Claudia (1977-2018). Editora Abril, São Paulo

24. Salerno MS, Vasconcelos Gomes LA, Silva DO, Bagno RB, Freitas SLTU (2015) Innovation processes: which process for which project? Technovation. https://doi.org/10.1016/j.technovati on.2014.07.012

25. Lipovetsky G (2009) O império do efêmero ("The ephemeral empire"). Companhia de Bolso, São Paulo

26. Caldas D (2004) Observatório de sinais: teoria e prática da pesquisa de tendências ("Observatory of signals: theory and practice of trend research). Senac, São Paulo

27. Markeviciute I, Blazenaite A (2011) Interaction between consumers and business agents in the fashion industry. Soc Moksl 72(2):35-43. https://doi.org/10.5755/j01.ss.71.2.537

28. Castro ABC (2016). Inovação e indústria da moda: um modelo de inovação em estilos e tendências ("Innovation and fashion industry: an innovation model in style and trends"). PhD Thesis, University of São Paulo

Publisher's Note Springer Nature remains neutral with regard to jurisdictional claims in published maps and institutional affiliations. 